Universidad de Lima

Facultad de Derecho

Carrera de Derecho

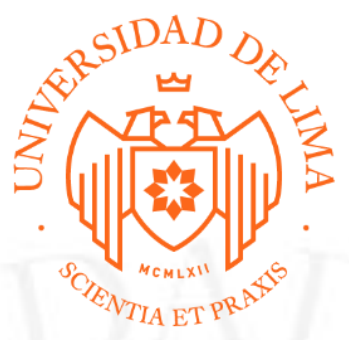

\title{
CIVIL: "NULIDAD DE ACUERDO SOCIETARIO" Y ADMINISTRATIVO: "PROTECCIÓN AL CONSUMIDOR"
}

Trabajo de suficiencia profesional para optar el Título Profesional de Abogado

Teresa Maria Leticia Alayza Valdivieso

Código 20131504

Lima - Perú

Febrero de 2019 


\section{CIVIL: "NULIDAD DE ACUERDO SOCIETARIO"}

Materia: Nulidad de Acuerdo Societario

No. De Expediente: 04901-2011-0-1817-JR-CO-16

\section{RESUMEN}

La empresa Demandada es una sociedad anónima debidamente constituida bajo las leyes del Perú que, de conformidad con lo estipulado en el artículo Vigésimo Noveno de su Estatuto cuenta con Directorio que debe estar conformado permanentemente por ocho miembros titulares. Según el artículo Trigésimo Sexto del mismo, el quórum es de siete directores.

Al 14 de noviembre de 2010, el Directorio de la Demandada se encontraba conformado por ocho Directores titulares y ocho Directores alternos. Con fecha 15 de noviembre de 2010 renunciaron dos Directores alternos y un Director titular. El 25 del mismo mes, una empresa, accionista de la Demandada (titular de $48.85 \%$ \%), solicitó al Directorio convocar a Junta General de Accionistas, acto que no fue cumplido. Posteriormente, el 21 de diciembre de 2010 renunció la Directora titular de la Demandada. Por tanto, el Directorio solo contaba con seis Directores titulares hábiles.

El 22 de diciembre de 2010, los Directores titulares hábiles de la Demandada sesionaron y acordaron designar a dos Directores titulares en reemplazo. Al respecto, el Registrador Público tachó el título bajo el cual se tramitó la inscripción del acuerdo, por considerar que no se habría sesionado respetando el quórum del Directorio. 


\section{ADMINISTRATIVO: "PROTECCIÓN AL CONSUMIDOR"}

Materia: Protección al Consumidor

No. De Expediente: 147-2010/CPC.

\section{RESUMEN}

El 14 de febrero de 2010, los Demandantes denunciaron a una Compañía de Seguros y de Reaseguros por presunta infracción al T.U.O de la Ley del Sistema de Protección al Consumidor (Decreto Supremo N006-2009-PCM) (en adelante, el T.U.O de la Ley del Sistema de Protección al Consumidor), señalando lo siguiente:

1.- Que, se adquirió una camioneta marca Honda, que tenía como finalidad el transporte particular. Al mismo tiempo se contrató una póliza de seguro que incluía la cobertura del robo total del vehículo.

2.-Se efectuó puntualmente los pagos mensuales durante el 2009.

3.-El 29 de junio de 2009, fueron víctimas del robo del vehículo asegurado, hecho que fue denunciado inmediatamente a la compañía, quienes señalaron que no darían cobertura al siniestro debido a que el vehículo no contaba con Sistema de Posicionamiento Global (GPS).

4.-Dicha condición no se encontraba establecida contractualmente y tampoco les fue informada oportunamente en la renovación del seguro en el 2009, siendo que incluso no contaban con la copia de esta nueva póliza.

Presentaron un reclamo contra el Demandado a través del Servicio de Atención al Ciudadano (SAC) del Instituto Nacional de Defensa de la Competencia y de la Protección de la Propiedad Intelectual (Indecopi). 